\title{
Analisis Webometrics terhadap Repositori Institusi Perguruan Tinggi Keagamaan Islam Negeri (PTKIN): Kajian terhadap 5 PTKIN di Indonesia
}

\author{
Budhi Santoso ${ }^{1 *}$ \\ ${ }^{1}$ Program Studi Ilmu Perpustakaan, Fakultas Adab dan Humaniora, UIN Raden Fatah Palembang \\ *Korespondensi: kangbudhi_uin@radenfatah.ac.id
}

\begin{abstract}
Institutional repository is a media for digital preservation of academic work in an institution. Institutional repositories are one tool for ranking institutions in the world. Researchers used webometrics analysis to rank institutional repository websites in 5 PTKAIN in Indonesia and then 4 indicators were used to assess institutional repositories namely; size indicator $(S)$, visibility indicator $(V)$, richfile indicator $(R)$, scholar indicator then the four indicators are analyzed to rank webometricss. From the research results of UIN Syarif Hidayatullah was ranked first with a value of 0.9932, then the second rank was UIN Sunan Kalijaga Yogyakarta with a value of 0.5486, then the third rank was UIN Sultan Syarif Kasim Riau with a value of 0.3916, fourth was UIS Walisongo Semarang with a value 0.2978 then the last rank is UIN Raden Fatah Palembang with a value of 0.2171. Efforts need to be made separately to improve the webometricss of the institution namely; The need for an information technology team in the library to study about search engine optimizer (SEO), the need for commitment from all academicians to support institutional repositories to develop and the need to preserve academic work in institutions by uploading all local content to institutional repositories such as pdf, word and ppt document formats.
\end{abstract}

Keywords: institutional repositories; webometrics; state islamic universities

\begin{abstract}
Abstrak
Repositori institusi merupakan media untuk preservasi digital karya akademis yang ada disebuah institusi. Repositori institusi merupakan salah satu alat untuk pemeringkatan institusi di dunia. Peneliti menggunakan analisis webometrics untuk pemeringkatan website repositori institusi di 5 PTKAIN di Indonesia kemudian ditetapkan 4 indikator yang digunakan untuk menilai repositori institusi yaitu; indikator size (S), indikator visibilitas (V), indikator rich file (R), indikator scholar kemudian keempat indikator tersebut dianalisis untuk menentukan peringkat webometricss. Dari hasil penelitian UIN Syarif Hidayatullah menempati peringkat pertama dengan nilai 0,9932, kemudian peringkat kedua adalah UIN Sunan Kalijaga Yogyakarta dengan nilai 0,5486, kemudian peringkat ketiga adalah UIN Sultan Syarif Kasim Riau dengan nilai 0.3916, peringkat keempat adalah UIN Walisongo Semarang dengan nilai 0.2978 kemudian peringkat terakhir adalah UIN Raden Fatah Palembang dengan nilai 0,2171. Upaya yang perlu dilakukan untuk mengingkatkan webometrik institusi yaitu; Perlunya dibuat sebuah tim teknologi informasi di perpustakaan yang mengkaji tentang search engine optimizer (SEO), perlunya komitment dari semua pihak sivitas akademika dalam mendukung repositori institusi untuk dapat berkembang dan perlunya upaya pelestarian karya akademis yang ada di institusi dengan mengunggah semua konten lokal ke repositori institusi dalam format dokumen pdf, word dan ppt.
\end{abstract}

Kata Kunci: repositori institusi; webometrik; perguruan tinggi keagamaan islam negeri

\section{PENDAHULUAN}

Perkembangan teknologi informasi dan komunikasi memberikan dampak yang besar terhadap distribusi dan penyimpanan karya ilmiah yang dihasilkan oleh institusi akademik, salah satunya dengan munculnya media penyimpan karya ilmiah yaitu repositori institusi. Semenjak diperkenalkan tahun 1990 repositori institusi mampu memberikan perubahan dalam hal cara preservasi karya akademik secara digital serta memudahkan dalam komunikasi akademik.

Dalam konteks komunikasi akademik, peran repositori institusional dianggap penting untuk memastikan bahwa proses tersebut dikelola oleh para peneliti. Jika repositori juga memasukkan layanan statistik, terhubung ke jejaring sosial dan bahkan menyertakan sistem peer review, mereka merupakan alternatif bagi sistem komunikasi akademik tradisional, sehingga mencapai penghematan besar dalam pendanaan penelitian dan memastikan bahwa penyebaran dan komunikasi sepenuhnya berada di tangan komunitas riset (Coar, 2017, p. 2). 
Selain komunikasi ilmiah, repositori institusi memiliki manfaat yaitu pelestarian jangka panjang karya yang dihasilkan oleh institusi akademik maupun institusi penelitian. Dengan adanya repositori institusi juga dapat meningkatkan visibilitas dan prestise, dan bertindak sebagai iklan untuk menarik sumber pendanaan, potensi dosen baru dan mahasiswa. Untuk individu, mereka menyediakan arsip utama dari pekerjaan peneliti, meningkatkan penyebarannya dan, berpotensi, berdampak terhadap komunitas penelitian, dan repositori institusi dapat bertindak sebagai curriculum vitae (CV) lengkap dari penulis dikarenakan semua hasil peneliti dikumpulkan di satu tempat (Westell, 2006, p. 211).

Hadirnya repositori institusi diharapkan dapat memenuhi kebutuhan civitas akademika terutama dalam hal publikasi penelitian terbuka yang dapat diakses dimana saja dan kapan saja tanpa terbatas waktu. Dalam dunia akademik repositori institusi dikelola oleh perpustakaan perguruan tinggi, sebagai pusat informasi perpustakaan yang mengemban misi yang tertuang dalam Tri Dharma Perguruan yaitu pendidikan, penelitian, dan pengabdian kepada masyarakat. Beberapa perpustakaan perguruan tinggi biasanya membangun repository yang isinya meliputi tugas akhir (skripsi, tesis, dan disertasi), jurnal-jurnal kampus, buku-buku yang dihasilkan oleh lembaga atau sivitas akademika, laporan-laporan penelitian, dan hasil-hasil kegiatan ilmiah atau non-ilmiah (Zulaikha, Sholihin, Marwiyah, \& Labibah, 2017, p. 2).

Repositori institusi merupakan salah satu elemen pendukung dalam visibilitas sebuah institusi dan menjadi salah satu faktor yang mendukung sebuah institusi akademik yaitu perguruan tinggi supaya dapat masuk dan berkompetisi dalam universitas kelas dunia atau world class university. Alat ukur untuk melihat pemeringkatan sebuah website adalah webometrics. Webometrics merupakan bagian dari kajian infometrik, dengan memanfaatkan metode bibliometrics serta scientometrics dalam cybermetrics, webometrics merupakan kajian yang lebih luas dibandingkan dengan yang lainnya (Andike \& Dewi, 2017, p. 12).

Pemeringkatan webometrics mempunyai 4 indikator yatitu indikator Size (S) adalah jumlah halaman dari repositori institusi yang ditemukan dari mesin pencari, indikator visibilitas (V) adalah jumlah link eksternal, indikator Rich file (R) yang merupakan kekayaan file yang dimiliki oleh sebuah repositori insititusi, serta indikator Scholar (Sc) adalah jumlah paper ilmiah milik insititusi yang ditemukan pada database google scholar (Bachtiar, 2107, p. 6).

Saat ini pemeringkatan webometricss repositori institusi dirilis oleh The Ranking Web of World Repositories (http://repositories.webometricss.info) merupakan database yang dapat digunakan untuk melihat dampak komunikasi ilmiah repository institusi sebuah perguruan tinggi. Database tersebut dapat merangking dan mengurutkan repository institusi yang memiliki dampak paling tinggi sampai paling rendah. Rangking juga dapat dilihat pada tataran dunia maupun terbatas secara regional saja, tergantung kebutuhan penggunanya (Prasetyawan, 2017, p. 42).

Pemeringkatan webometrics terbaru dirilis pada bulan Januari 2019. Pada pemeringkatan webometrics repositori institusi yang dirilis oleh Cybermetrics Lab, National Research Council (CSIC) Universitas Gadjah Mada menduduki peringkat satu nasional sedangkan UIN Syarif Hidayatullah menempati peringkat pertama repositori institusi di Perguruan Tinggi Keagamaan Islam Negeri (PTKIN) menyusul UIN Sultan Syarif Kasim Riau, UIN Walisongo Semarang, UIN Sunan Kalijaga Yogyakarta, UIN Raden Fatah Palembang. Penelian ini memfokuskan pada repositori institusi PTKIN, Penelitian ini menurut penulis penting dilakukan karena hasil dari penelitian ini dapat menjadi informasi yang berguna bagi PTKIN lain dan rekomendasi dalam mengembangkan repositori institusi.

\section{METODE PENELITIAN}

Penelitian ini menggunakan deskritif kuantitatif. Penelitian deskriptif kuantitatif merupakan usaha sadar dan sistematis untuk memberikan jawaban terhadap suatu masalah dan atau 
mendapatkan informasi lebih mendalam dan luas terhadap suatu fenomena dengan menggunakan tahap-tahap penelitian dengan pendekatan kuantitatif (Yusuf, 2017, p. 62). Dalam penelitian ini penulis menggunakan kajian webometrics yang digunakan untuk mengukur aspek website, halaman web, bagian dari halaman website, kata-kata di dalam website, hyperlinks, dan hasil pencarian website (Thelwall, 2009, p. 1). Penulis menggunakan 4 indikator untuk mengukur webometrics dan menilai repositori institusi adapun indikatornya yaitu; indikator size (S), indikator visibilitas (V), indikator rich file (R), dan indikator scholar. Keempat indikator tersebut dianalisis untuk menentukan peringkat webometricss. Setelah diketahi peringkat dari masingmasing indikator, kemudian dideskripsikan dan dianalisis indikator webometricss terhadap website repositori insitiusi 5 Perguruan Tinggi Keagamaan Islam Negeri.

\section{Teknik Pengumpulan Data}

Teknik pengumpulan data merupakan bagian dari tahapan penelitian langkah yang cukup strategis karena tujuan utama dari penelitian adalah mendapatkan data untuk dianalisis lebih lanjut. Tanpa mengetahui teknik pengumpulan data, maka peneliti tidak akan mendapatkan data yang memenuhi standar data yang ditetapkan (Sugiyono, 2013, p. 224). Pengumpulan data dalam penelitian ini menggunakan teknik studi literatur dan obeservasi.

Penulis melakukan observasi dengan mengamati dan menganalisis hasil-hasil penelusuran pada perangkat indikator webometricss terhadap 5 website repositori institusi Perguruan Tinggi Keagamaan Islam Negeri (PTKIN). Adapun daftar repositori insitutusi PTKIN yang diobservasi oleh peneliti seperti tabel dibawah ini:

Tabel 1

Daftar repositori institusi 5 PTKN di Indonesia

\begin{tabular}{cll}
\hline No & \multicolumn{1}{c}{ Institusi } & \multicolumn{1}{c}{ Alamat Repositori } \\
\hline 1 & UIN Sultan Syarif Kasim Riau & $\underline{\text { http://repository.uin-suska.ac.id/ }}$ \\
2 & UIN Walisongo Semarang & $\underline{\text { http://eprints.walisongo.ac.id/ }}$ \\
3 & UIN Syarif Hidayatullah & $\underline{\mathrm{http} / / / \text { repository.uinjkt.ac.id/dspace/ }}$ \\
4 & UIN Sunan Kalijaga Yogyakarta & $\underline{\text { http:///eprigilib.uin-suka.ac.id/ }}$ \\
5 & UIN Raden Fatah Palembang & $\underline{.}$ \\
\hline
\end{tabular}

Website repositori institusi kemudian dianalisis menggunakan keyword pencarian di google untuk mencari Size $(\mathrm{S})$, Rich file $(R)$, untuk mencari visibilitas penulis menggunakan portal backlink checker Ahref (https://ahrefs.com) adalah seperangkat alat yang berguna untuk backlink dan analisis search engine optimizer (SEO) (Helen, 2019). Sedangkan untuk mengetahui jumlah artikel di scholar penulis menggunakan portal google scholar. Google Scholar merupakan salah satu layanan dalam Google yang sangat bermanfaat dalam membuat karya ilmiah karena menyediakan literature ilmiah dari berbagai disiplin ilmu baik yang berupa buku, abstrak, maupun artikel. Literature ilmiah sifatnya lebih dapat dipertanggungjawabkan jika digunakan untuk referensi penulisan karya tulis ilmiah dibandingkan artikel-artikel lain yang umumnya belum di review. Google Scholar dapat dibuka dilaman http://scholar.google.com/ (Tiara, Rahardja, \& Rosalinda, 2016, p. 96). Adapun query pencarian indikator webometricss dijabarkan seperti tabel di bawah ini :

Tabel 2

Query pencarian indikator webometricss

\begin{tabular}{lll}
\hline Indikator & Mesin pencari & Query \\
\hline Size (S) & Google & Site: http://eprints.radenfatah.ac.id \\
Visibilitas (V) & Ahref & Site: http://eprints.radenfatah.ac.id \\
Rich file (R) & Google & Site: http://eprints.radenfatah.ac.id; filetype: pdf dan doc \\
Scholar (Sc) & Google Scholar & Site: http://eprints.radenfatah.ac.id \\
\hline
\end{tabular}


Setelah mendapatkan data-data yang diperlukan dari mesin pencari, data tersebut akan dinormalisasi menggunakan persamaan dari Auguillo yaitu :

$\mathrm{Na}=\log (\mathrm{na}+1) / \log (\max (\mathrm{ni})+1)$

$\mathrm{Na}$ adalah nilai normalisasi. na merupakan nilai yang didapat dari mesin pencari. Max(ni) merupakan nilai na yang palinggi tinggi dari seluruh perguruan tinggi (Isidiro F Aguillo, 2009, p. $37)$.

Kemudian untuk mendapatkan nilai webometricss, masing-masing indikator tersebut diberi bobot, yaitu Size (S) jumlah dari halaman web 20\%, Rich files (R) jumlah dari dokumen 15\%, scholar (Sc) jumlah artikel 15\%, visibilititas (V) jumlah link eksternal atau backlink 50\% (Isidro F. Aguillo, Ortega, Fernández, \& Utrilla, 2010, p. 481)

\section{HASIL DAN PEMBAHASAN}

Webometrics merupakan Studi tentang fitur kuantitatif, karakteristik, struktur dan pola penggunaan world wide web, hyperlink, dan sumber daya internet (Lukman, Hidayat, Al-Hakim, \& Nadhiroh, 2019, p. 15). Dalam penelitian ini penulis menggunakan penelitian kuantitatif dengan menganalisis 5 sampel Perguruan Tinggi Keagamaan Islam Negeri (PTKIN) dengan mencari nilai dari masing-masing indikator kemudian menentukan nilai max(ni) setiap indikator setelah nilai max(ni) diketahui baru dilakukan normalisasi.

\section{Nilai Max (ni)}

Nilai Max digunakan untuk pencarian nilai maksimal dari setiap indikator, Pencarian nilai maksimal dari setiap indikator ditentukan berdasarkan pencarian nilai dalam setiap indikator dari subjek penelitian. Pencarian nilai max digunakan sebagai pembanding pada perhitungan normalisasi untuk masing-masing indikator.

\section{Nilai max(ni) Indikator Size (S)}

Indikator Size (s) didapatkan dari penelusuran menggunakan mesin pencari Google. Mesin pencari Google dipilih karena volume indeks oleh Google lebih besar dibandingkan dengan mesin pencari lainnya, dimana Google menduduki peringkat pertama berdasarkan volume indeks yaitu sebesar 68,09\%, dan sisanya dimiliki oleh mesin pencari lainnya (Muntashir, 2011, p. 40).

Hasil yang didapat dari penelusuran di mesin pencari google adalah hasil terbesar dimiliki oleh UIN Sultan Syarif Kasim Riau dengan hasil pencarian sebanyak 102,000 halaman. Artinya, pada indikator size ini, UIN Sultan Syarif Kasim Riau memiliki jumlah halaman website repositori institusi yang diindex oleh mesin pencari google sebanyak 102,000 halaman. Ini berarti jumlah halaman website repositori institusi dari UIN Sultan Syarif Kasim Riau akan menjadi pembanding dalam penghitungan nilai indikator Size (S) untuk semua subjek penelitian. Penyebut dari penghitungan nilai indikator Size $(S)$ ialah $\log 102,000+1$. Hasil penelelusuran untuk indikator Size (S) sebagai berikut:

Tabel 3

Hasil penelusuran indikator Size $(\mathrm{S})$

\begin{tabular}{lll}
\hline No & Repositori Institusi & Hasil \\
\hline 1 & UIN Sultan Syarif Kasim Riau & 102,000 \\
2 & UIN Walisongo Semarang & 85,700 \\
3 & UIN Syarif Hidayatullah & 77,300 \\
4 & UIN Sunan Kalijaga Yogyakarta & 49,500 \\
5 & UIN Raden Fatah Palembang & 9,230 \\
\hline
\end{tabular}

2. Nilai max(ni) indikator Visibility (V)

Adapun cara menghitung indikator visibility pada subjek penelitian, diperlukan nilai maksimal dari keseluruhan hasil penelurusuran jumlah backlink pada masing-masing repositori. Penelusuran ini dilakukan menggunakan sebuah fasilitas dari Ahrefs 
(https://ahrefs.com/backlink-checker), yaitu sebuah website yang menyediakan layanan untuk mengetahui jumlah link dari website repository, website repository yang masuk ke sebuah halaman website lain atau backlink.

Hasil penelusuran yang didapatkan adalah repository institiusi milik UIN Syarif Hidayatullah memiliki jumlah backlink terbanyak diantara subjek lainnya yaitu sebanyak 3,146, dengan jumlah ini repositori institusi UIN Syarif Hidayatullah memiliki jumlah terbanyak backlink dari repositori institusi lainnya sehingga akan menjadi penyebut dalam penghitungan nilai indikator Visibility (V) untuk semua subjek penelitian. Adapun hasil dari penelusuran backlink melalui penelusuran dengan Ahrefs didapatakan hasil sebagai berikut :

Tabel 4

Hasil penelusuran indikator Visibility $(\mathrm{V})$

\begin{tabular}{llc}
\hline No & \multicolumn{1}{c}{ Repositori Institusi } & Hasil \\
\hline 1 & UIN Sultan Syarif Kasim Riau & 17 \\
2 & UIN Walisongo Semarang & 173 \\
3 & UIN Syarif Hidayatullah & 3,146 \\
4 & UIN Sunan Kalijaga Yogyakarta & 2,076 \\
5 & UIN Raden Fatah Palembang & 99 \\
\hline
\end{tabular}

\section{Nilai max(ni) indikator Rich file (R)}

Perhitungan rich file menggunakan 3 jenis ekstensi file dokumen yang digunakan sebagai nilai hitung dari indikator ini. Adapun 3 jenis ekstensi file yang digunakan sebagai nilai hitung dari indikator ini yaitu ekstensi file dokumen yang sering digunakan untuk konten repositori institusi yaitu Portable document format (PDF), Document (DOC) dan Power Point (PPT). Berdasarkan hasil penelusuran menggunakan mesin pencari google didapatkan hasil repositori institusi UIN Sultan Syarif Kasim Riau mempunyai jumlah kumulatif file terbanyak dari ketiga format. Maka dari itu jumlah file UIN Sultan Syarif Kasim Riau menjadi pembagi atau penyebut pada penghitungan indikator nilai Rich file. Adapun hasil penelusuran untuk indikator Richfile (R) yang didapat adalah sebagai berikut:

a) Format PDF

Tabel 5

Hasil penelusuran indikator rich file PDF.

\begin{tabular}{lll}
\hline No & \multicolumn{1}{c}{ Repositori Institusi } & Hasil \\
\hline 1 & UIN Sultan Syarif Kasim Riau & 83,300 \\
2 & UIN Walisongo Semarang & 41,200 \\
3 & UIN Syarif Hidayatullah & 27,200 \\
4 & UIN Sunan Kalijaga Yogyakarta & 5,860 \\
5 & UIN Raden Fatah Palembang & 4,120 \\
\hline
\end{tabular}

b) Format DOC.

Tabel 6

Hasil penelusuran indikator Rich file DOC.

\begin{tabular}{llc}
\hline No & \multicolumn{1}{c}{ Repositori Institusi } & Hasil \\
\hline 1 & UIN Sultan Syarif Kasim Riau & 4 \\
2 & UIN Walisongo Semarang & 1 \\
3 & UIN Syarif Hidayatullah & 16 \\
4 & UIN Sunan Kalijaga Yogyakarta & 10 \\
5 & UIN Raden Fatah Palembang & 41 \\
\hline
\end{tabular}

c) Format PPT

Tabel 7

Hasil penelusuran indikator Rich file PPT.

\begin{tabular}{llll}
\hline No & \multicolumn{1}{c}{ Repositori Institusi } & Hasil \\
\hline 1 & UIN Sultan Syarif Kasim Riau & - & \\
2 & UIN Walisongo Semarang & 1 & \\
3 & UIN Syarif Hidayatullah & - & \\
4 & UIN Sunan Kalijaga Yogyakarta & 8 & \\
5 & UIN Raden Fatah Palembang & 2 & \\
\hline
\end{tabular}




\section{Nilai max(ni) indikator Scholar (Sc)}

Sebelum menghitung indikator Scholar (Sc) pada subjek penelitian, diperlukan nilai maksimal dari keseluruhan hasil penelurusuran jumlah file scholar pada masing-masing repositori. Penelusuran ini dilakukan menggunakan sebuah mesin pencari Google Scholar.

Hasil penelusuran yang didapat adalah, website institusi repositori milik UIN Syarif Hidayatullah memiliki jumlah file Scholar terbanyak diantara subjek lainnya yaitu sebanyak 37.600. Ini berarti jumlah file scholar milik website repositori institusi UIN Syarif Hidayatullah menjadi penyebut atau pembagi dalam penghitungan nilai indikator rich file $(\mathrm{R})$ untuk semua subjek penelitian. Penyebut dari penghitungan nilai indikator Richfile (R) adalah log $37.600+1$. Hasil penelusuran nilai maksimal untuk indikator scholar adalah sebagai berikut:

Tabel 8

Hasil penelusuran indikator Scholar (Sc).

\begin{tabular}{lll}
\hline No & \multicolumn{1}{c}{ Repositori Institusi } & \multicolumn{1}{c}{ Hasil } \\
\hline 1 & UIN Sultan Syarif Kasim Riau & 16.600 \\
2 & UIN Walisongo Semarang & 9.580 \\
3 & UIN Syarif Hidayatullah & 37.600 \\
4 & UIN Sunan Kalijaga Yogyakarta & 466 \\
5 & UIN Raden Fatah Palembang & 2.600 \\
\hline
\end{tabular}

\section{Indikator Size (S)}

Indikator Size menunjukan seberapa besar jumlah halaman dari website repository institusi ditemukan oleh mesin pencari. Dalam hal ini, size menunjukan besarnya mesin pencari Google mengindeks atau menemukan halaman dari website institusi repositori. Hasil penelusuran yang dilakukan peneliti untuk indikator Size menunjukan bahwa insititusi repositori milik UIN Sultan Syarif Kasim Riau memperoleh hasil terbanyak dengan dengan nilai normalisasi sebesar 1 atau sebanyak 102,000 halaman yang diindeks oleh mesin pencari Google. Sedangkan untuk halaman website institusi repositori terkecil adalah milik UIN Raden Fatah Palembang dengan nilai normalisasi 9,230 halaman.

Hasil perhitungan untuk indikator Size (S) pada masing-masing institusi repositori ialah sebagai berikut:

Tabel 9

Hasil perhitungan indikator Size (S)

\begin{tabular}{|c|c|c|c|c|}
\hline No & Repositori Institusi & $\begin{array}{c}\text { Jumlah } \\
\text { Halaman }\end{array}$ & Normalisasi Size & Hasil \\
\hline \multirow[t]{2}{*}{1} & \multirow[t]{2}{*}{ UIN Sultan Syarif Kasim Riau } & \multirow{2}{*}{102,000} & $\log (102.000+1)$ & \multirow[t]{2}{*}{1} \\
\hline & & & $\overline{\log (102.000+1)}$ & \\
\hline \multirow[t]{2}{*}{2} & \multirow[t]{2}{*}{ UIN Walisongo Semarang } & \multirow[t]{2}{*}{85,700} & $\log (85.700+1)$ & \multirow[t]{2}{*}{0,84019} \\
\hline & & & $\overline{\log (102.000+1)}$ & \\
\hline \multirow[t]{2}{*}{3} & \multirow[t]{2}{*}{ UIN Syarif Hidayatullah } & \multirow[t]{2}{*}{77,300} & $\log (77.300+1)$ & \multirow[t]{2}{*}{0,757845} \\
\hline & & & $\overline{\log (102.000+1)}$ & \\
\hline \multirow[t]{2}{*}{4} & \multirow[t]{2}{*}{ UIN Sunan Kalijaga Yogyakarta } & \multirow[t]{2}{*}{49,500} & $\log (49.500+1)$ & \multirow[t]{2}{*}{0,48529} \\
\hline & & & $\overline{\log (102.000+1)}$ & \\
\hline \multirow[t]{2}{*}{5} & \multirow[t]{2}{*}{ UIN Raden Fatah Palembang } & \multirow[t]{2}{*}{9,230} & $\log (9.230+1)$ & \multirow[t]{2}{*}{0,090499} \\
\hline & & & $\log (102.000+1)$ & \\
\hline
\end{tabular}

\section{Indikator Visibilitas (V)}

Indikator visibility adalah indikator yang menunjukkan seberapa banyak link eksternal atau backlink yang dimiliki oleh website repository institusi. Dalam indikator visibility, semakin banyak jumlah link eksternal yang dimiliki oleh sebuah repositori institusi menandakan semakin banyak pula sebuah halaman website lain menyematkan link dari website repositori institusi di 
dalam halaman website tersebut. Untuk memperoleh data pada indikator visibility ini, peneliti menggunakan sebuah layanan dari website Ahrefs (https://ahrefs.com/backlink-checker), sebuah website yang memungkinkan kita mengetahui jumlah backlink yang dimiliki oleh sebuah halaman website, termasuk repositori institusi.

Hasil penelusuran yang dilakukan peneliti untuk indikator Visibility ini menunjukan bahwa insititusi repositori milik UIN Syarif Hidayatullah memperoleh hasil terbanyak dengan dengan nilai normalisasi sebesar 1 atau sebanyak 3,146 backlink. Sedangkan UIN Sultan Syarif Kasim Riau memiliki jumlah backlink yang paling sedikit dibandingkan institusi repositori lainnya pada indikator ini yaitu memperoleh 17 backlink. Hasil perhitungan untuk indikator Visibility (V) pada masing-masing institusi repositor ialah sebagai berikut:

Tabel 10

Hasil perhitungan indikator Visibility (V)

\begin{tabular}{|c|c|c|c|c|}
\hline No & Repositori Institusi & Jumlah & Normalisasi Size & Hasil \\
\hline \multirow[t]{2}{*}{1} & \multirow{2}{*}{ UIN Sultan Syarif Kasim Riau } & \multirow[t]{2}{*}{17} & $\log (17+1)$ & \multirow[t]{2}{*}{0.0057} \\
\hline & & & $\log (3.146+1)$ & \\
\hline \multirow[t]{2}{*}{2} & \multirow[t]{2}{*}{ UIN Walisongo Semarang } & \multirow[t]{2}{*}{173} & $\log (173+1)$ & \multirow[t]{2}{*}{0.0552} \\
\hline & & & $\log (3.146+1)$ & \\
\hline \multirow[t]{2}{*}{3} & \multirow[t]{2}{*}{ UIN Syarif Hidayatullah } & \multirow[t]{2}{*}{3,146} & $\log (3.146+1)$ & \multirow[t]{2}{*}{1} \\
\hline & & & $\overline{\log (3.146+1)}$ & \\
\hline \multirow[t]{2}{*}{4} & \multirow{2}{*}{$\begin{array}{l}\text { UIN Sunan } \\
\text { Yogyakarta }\end{array}$} & \multirow[t]{2}{*}{2,076} & $\log (2.076+1)$ & \multirow[t]{2}{*}{0.6599} \\
\hline & & & $\overline{\log (3.146+1)}$ & \\
\hline \multirow[t]{2}{*}{5} & \multirow[t]{2}{*}{ UIN Raden Fatah Palembang } & \multirow[t]{2}{*}{99} & $\log (99+1)$ & \multirow[t]{2}{*}{0.0317} \\
\hline & & & $\log (3.146+1)$ & \\
\hline
\end{tabular}

\section{Indikator rich file $(\mathbf{R})$}

Indikator Richfile ini menunjukkan jumlah keberagaman tipe file yang terdapat pada repositori institusi masing-masing subjek dalam hal ini 5 repositori institusi PTKIN di Indonesia. Tipe ekstensi file yang diperlukan dalam penelitian ini adalah portable document format (PDF), document (DOC), dan power point (PPT). Hal ini akan menunjukan kekeyaan dan kelengkapan file yang dimiliki oleh masing-masing repositori institusu. Cara penghitungan rich file adalah diaparkan hasil penelusuran dari masing-masing tipe file. Kemudian, dari masing-masing jumlah ketiga tipe file akan dijumlahkan kemudian dibagi dengan 3, karena pada penelitian ini menggunakan 3 jenis file yaitu PDF, DOC, dan PPT.

1)PDF

Tipe file PDF merupakan type file yang sangat umum ditemukan pada setiap perpustakaan digital. Karena itu, sebagian besar repositori institusi pada berbagai perguruan tinggi berisi filefile PDF, Baik itu skripsi, tesis, disertasi, maupun karya tulis lain yang dihasilkan para civitas institusi terkait. Hasil perhitungan untuk tipe file ini adalah sebagai berikut:

Tabel 11

Hasil perhitungan tipe file PDF

\begin{tabular}{|c|c|c|c|c|}
\hline No & Repositori Institusi & Jumlah & Normalisasi PDF & Hasil \\
\hline \multirow[t]{2}{*}{1} & \multirow[t]{2}{*}{ UIN Sultan Syarif Kasim Riau } & \multirow[t]{2}{*}{83,300} & $\log (83.300+1)$ & \multirow[t]{2}{*}{1} \\
\hline & & & $\overline{\log (83.300+1)}$ & \\
\hline \multirow[t]{2}{*}{2} & \multirow[t]{2}{*}{ UIN Walisongo Semarang } & \multirow[t]{2}{*}{41,200} & $\log (41.200+1)$ & \multirow[t]{2}{*}{0,49460390} \\
\hline & & & $\sqrt{\log (83.300+1)}$ & \\
\hline \multirow[t]{2}{*}{3} & \multirow[t]{2}{*}{ UIN Syarif Hidayatullah } & \multirow[t]{2}{*}{27,200} & $\log (27.200+1)$ & \multirow[t]{2}{*}{0,32653869} \\
\hline & & & $\sqrt{\log (83.300+1)}$ & \\
\hline
\end{tabular}




\begin{tabular}{lll|ll}
4 & UIN Sunan Kalijaga Yogyakarta & 5,860 & $\mid \frac{\mid \log (5.860+1)}{\log (83.300+1)}$ & 0,07035929 \\
5 & UIN Raden Fatah Palembang & 4,120 & $\mid \frac{\log (4.120+1)}{\log (83.300+1)}$ & 0,04947119 \\
\hline
\end{tabular}

\section{2)DOC}

Indikator richfile selanjutnya adalah format DOC. Format dokumen adalah format yang sering digunakan untuk membuat dokumen akademik seperti laporan penelitian, makalah, sekripsi, tesis dan disertasi. Untuk keperluan akademik dokumen dalam format akademik diubah menjadi format PDF. Fotmat DOC ini sangat familiar pada kalangan akademik. Repositori institusi UIN Raden Fatah memperoleh jumlah dokumen terbanyak yaitu 41 file dokumen. Adapun hasil perhitungan untuk tipe file DOC dalam indikator rich file ialah sebagai berikut:

Tabel 12

Hasil perhitungan tipe file DOC

\begin{tabular}{llclc}
\hline No & Repositori Institusi & Jumlah & Normalisasi DOC & Hasil \\
\hline 1 & UIN Sultan Syarif Kasim Riau & 4 & $\mid \frac{\log (4+1)}{\log (41+1)}$ & 0,11904761 \\
2 & UIN Walisongo Semarang & 1 & $\frac{\log (1+1)}{\log (41+1)}$ & 0,04761904 \\
3 & UIN Syarif Hidayatullah & 16 & $\mid \frac{\log (16+1)}{\log (41+1)}$ & 0,40476190 \\
4 & UIN Sunan Kalijaga Yogyakarta & 10 & $\mid \frac{\log (10+1)}{\log (41+1)}$ & \multirow{2}{*}{0,26190476} \\
5 & UIN Raden Fatah Palembang & 41 & $\mid \frac{\log (41+1)}{\log (41+1)}$ & 1 \\
& & &
\end{tabular}

3)PPT

Tipe file yang ketiga dalam indikator rich file ialah PPT. Tipe file ini sangat familiar digunakan kalangan akademik untuk keperluan persentasi serta pengajaran. Tipe file PPT dibuat dengan menggunakan perangkat lunak Microsoft Office Power Point. Hasil perhitungan yang diperoleh untuk tipe file PPT yang terbanyak adalah repositori institusi dari UIN Sunan Kalijaga Yogyakarata. Adapun perhitungan dari masing-masing repositori institusi adalah sebagai berikut:

Tabel 13

Hasil perhitungan tipe file PPT

\begin{tabular}{llccc}
\hline No & Repositori Institusi & Jumlah & Normalisasi PDF & Hasil \\
\hline 1 & $\begin{array}{l}\text { UIN Sultan Syarif Kasim } \\
\text { Riau }\end{array}$ & 0 & $\mid \frac{\log (0+1)}{\log (8+1)}$ & 0,11111111 \\
2 & $\begin{array}{l}\text { UIN Walisongo } \\
\text { Semarang }\end{array}$ & 1 & $\mid \frac{\log (1+1)}{\log (8+1)}$ & 0,22222222 \\
3 & UIN Syarif Hidayatullah & 0 & $\mid \frac{\log (0+1)}{\log (8+1)}$ & 0,11111111 \\
4 & $\begin{array}{l}\text { UIN Sunan Kalijaga } \\
\text { Yogyakarta }\end{array}$ & 8 & $\mid \frac{\log (8+1)}{\log (8+1)}$ & 1 \\
5 & $\begin{array}{l}\text { UIN Raden Fatah } \\
\text { Palembang }\end{array}$ & 2 & $\mid \frac{\log (2+1)}{\log (8+1)}$ & 0.33333333 \\
\hline
\end{tabular}

Hasil perhitungan pada indikator rich file yang telah dinormalisasi seperti tabel dibawah ini: 
Tabel 14

Hasil perhitungan indikator Rich file (R)

\begin{tabular}{|c|c|c|c|}
\hline No & Repositori Institusi & Normalisasi Rich File & Hasil \\
\hline 1 & $\begin{array}{l}\text { UIN Sultan Syarif Kasim } \\
\text { Riau }\end{array}$ & $1 / 3+1+0,11904+0,1111$ & 1,5634 \\
\hline 2 & $\begin{array}{ll}\text { UIN } & \text { Walisongo } \\
\text { Semarang } & \end{array}$ & $1 / 3+0,4946+0,0476+0,2222$ & 1,0977 \\
\hline 3 & UIN Syarif Hidayatullah & $1 / 3+0,3265+0,4047+0,1111$ & 1,1756 \\
\hline 4 & $\begin{array}{l}\text { UIN Sunan Kalijaga } \\
\text { Yogyakarta }\end{array}$ & $1 / 3+0,07035929+0,26190476+1$ & 1,6655 \\
\hline 5 & $\begin{array}{l}\text { UIN Raden Fatah } \\
\text { Palembang }\end{array}$ & $1 / 3 \times 0.728103+0.798524+0$ & 1,7161 \\
\hline
\end{tabular}

\section{Indikator Scholar}

Indikator ini memanfaatkan fitur pencarian google untuk pencarian dokumen ilmiah yaitu google scholar atau google cendekia (http://www.scholar.google.co.id). Google scholar ini memungkinkan untuk menemukan tulisan-tulisan ilmiah repositori institusi yang tersebar di dunia maya, dan telah terindeks oleh google scholar. Repositori institusi yang dapat terindeks google scholar diantaranya Eprints, DSpace dan sistem repositori institusi buatan sendiri yang mempunyai standar sesuai kebijakan google scholar. digunakan oleh seluruh institusi repositori yang menjadi subjek dalam penelitian ini. Selain menggunakan sistem repositori institusi, artikel ilmiah yang dihasilkan suatu lembaga juga dapat didaftarkan untuk diindeks oleh google scholar. Hasil perhitungan yang diperoleh untuk indikator google scholar dari masing-masing institusi repositori adalah sebagai berikut:

Tabel 15

Hasil perhitungan indikator Scholar (Sc)

\begin{tabular}{|c|c|c|c|c|}
\hline No & Repositori Institusi & Jumlah & Normalisasi Scholar & Hasil \\
\hline \multirow[t]{2}{*}{1} & \multirow{2}{*}{$\begin{array}{c}\text { UIN Sultan Syarif Kasim } \\
\text { Riau }\end{array}$} & \multirow[t]{2}{*}{16.600} & $\log (16.600+1)$ & \multirow[b]{2}{*}{0.4415} \\
\hline & & & $\overline{\log (37.600+1)}$ & \\
\hline \multirow[t]{2}{*}{2} & \multirow{2}{*}{$\begin{array}{l}\text { UIN Walisongo } \\
\text { Semarang }\end{array}$} & \multirow[t]{2}{*}{9.580} & $\log (9.580+1)$ & \multirow[b]{2}{*}{0.2548} \\
\hline & & & $\overline{\log (37.600+1)}$ & \\
\hline \multirow[t]{2}{*}{3} & \multirow[t]{2}{*}{ UIN Syarif Hidayatullah } & \multirow[t]{2}{*}{37.600} & $\log (37.600+1)$ & \multirow[b]{2}{*}{1} \\
\hline & & & $\overline{\log (37.600+1)}$ & \\
\hline \multirow[t]{2}{*}{4} & \multirow{2}{*}{$\begin{array}{c}\text { UIN Sunan Kalijaga } \\
\text { Yogyakarta }\end{array}$} & \multirow[t]{2}{*}{466} & $\log (466+1)$ & \multirow[b]{2}{*}{0.0124} \\
\hline & & & $\log (37.600+1)$ & \\
\hline \multirow[t]{2}{*}{5} & \multirow{2}{*}{$\begin{array}{l}\text { UIN Raden Fatah } \\
\text { Palembang }\end{array}$} & \multirow[t]{2}{*}{2.600} & $\log (2.600+1)$ & \multirow{2}{*}{0.0691} \\
\hline & & & $\overline{\log (37.600+1)}$ & \\
\hline
\end{tabular}

\section{Analisis Webometricss Repositori Institusi}

Setelah didapatkan hasil dari masing-masing indikator, langkah selanjutnya yaitu menentukan nilai webometricss. Nilai webometricss ditentukan dari pembobotan masing-masing indikator dimana indikator Visibility diberi bobot 50\%, Size 10\%, Rich File 10\%, dan Scholar sebanyak $30 \%$. Data nilai dari masing-masing indikator dijabarkan dalam tabel berikut:

Tabel 16

Data nilai masing-masing indikator setiap institusi repositori

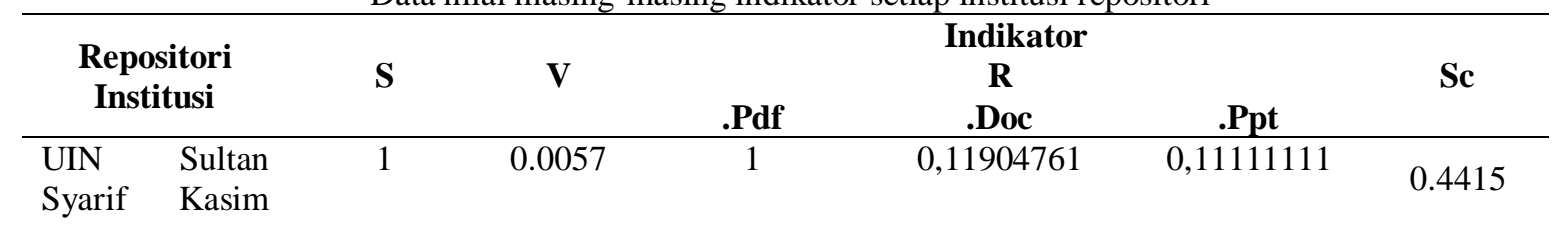




\begin{tabular}{lcccccc}
\hline Riau & & & & & & \\
UIN Walisongo & 0,840197 & 0.0552 & 0,49460390 & 0,04761904 & 0,22222222 & 0.2548 \\
$\begin{array}{l}\text { Semarang } \\
\text { UIN Syarif }\end{array}$ & 0,757845 & 1 & 0,32653869 & 0,40476190 & 0,11111111 & 1 \\
$\begin{array}{l}\text { Hidayatullah } \\
\text { UIN Sunan }\end{array}$ & 0,485299 & 0.6599 & 0,07035929 & 0,26190476 & 1 & \\
$\begin{array}{l}\text { Kalijaga } \\
\text { Yogyakarta }\end{array}$ & & & & & & 0.0124 \\
UIN Raden & 0,090499 & 0.0317 & 0,04947119 & 1 & 0.33333333 & \\
$\begin{array}{l}\text { Fatah } \\
\text { Palembang }\end{array}$ & & & & & & 0.0691 \\
\hline
\end{tabular}

Pada pemeringkatan ini dapat diketahui masing-masing kekurangan serta kelebihan dari setiap repositori institusi. Dari kelima repositori institusi PTKIN, repositori institusi UIN Syarif Hidayatullah mendapatkan nilai pembobotan paling tinggi, namun tidak berarti unggul dalam semua indikator. Dalam indikator rich file UIN Raden Fatah lebih unggul dibandingkan dengan UIN Syarif Hidayatullah. Namun secara keseluruhan, UIN Syarif Hidayatullah mendapatkan nilai yang paling tinggi diantara repositori institusi lainnya. Pada peringkat kedua ditempati oleh repositori institusi UIN Sunan Kalijaga Yogyakarta dengan mendapat nilai sebesar 1,6655. Secara keseluruhan UIN Raden Fatah Palembang unggul dalam richfile.

Pada pemeringkatan webometrics repositori institusi milik UIN Syarif Hidayatullah menempati posisi pertama dalam pemeringkatan webometricss dengan mendapatkan nilai sebesar 0,9932. Kemudian pada peringkat kedua UIN Sunan Kalijaga Yogyakarta dengan mendapatkan hasil 0,5486, peringkat tiga UIN Sultan Syarif Kasim Riau dengan mendapatkan nilai sebesar 0.3916, peringkat empat UIN Walisongo Semarang dengan mendapatkan nilai sebesar 0.2978 dan peringkat lima yaitu UIN Raden Fatah Palembang dengan mendapatkan nilai 0,2171. Hasil nilai lengkap dari masing-masing indikator serta pemeringkatan webometricss dapat dilihat pada tabel berikut ini:

Tabel 17

Data nilai masing-masing indikator setiap institusi repositori

\begin{tabular}{|c|c|c|c|c|c|c|c|}
\hline $\begin{array}{l}\text { Repositori } \\
\text { Institusi }\end{array}$ & $\mathbf{S}$ & V & .Pdf & $\begin{array}{c}\text { Indikator } \\
\mathbf{R} \\
\text {.Doc }\end{array}$ & .Ppt & Sc & $\begin{array}{c}\text { Nilai } \\
\text { Webometricss }\end{array}$ \\
\hline $\begin{array}{ll}\text { UIN } & \text { Sultan }\end{array}$ & 1 & 0.0057 & 1 & 0,11904761 & 0,1111 & & \\
\hline $\begin{array}{l}\text { Syarif } \\
\text { Kasim Riau }\end{array}$ & & & & & & 0.4415 & 0.3916 \\
\hline $\begin{array}{l}\text { UIN } \\
\text { Walisongo } \\
\text { Semarang }\end{array}$ & 0,840197 & 0.0552 & 0,49460390 & 0,04761904 & 0,2222 & 0.2548 & 0.2978 \\
\hline $\begin{array}{l}\text { UIN Syarif } \\
\text { Hidayatullah }\end{array}$ & 0,757845 & 1 & 0,32653869 & 0,40476190 & 0,1111 & 1 & 0,9932 \\
\hline $\begin{array}{l}\text { UIN Sunan } \\
\text { Kalijaga } \\
\text { Yogyakarta }\end{array}$ & 0,485299 & 0.6599 & 0,07035929 & 0,26190476 & 1 & 0.0124 & 0,5486 \\
\hline $\begin{array}{l}\text { UIN Raden } \\
\text { Fatah } \\
\text { Palembang }\end{array}$ & 0,090499 & 0.0317 & 0,04947119 & 1 & 0.3333 & 0.0691 & 0,2171 \\
\hline
\end{tabular}

\section{SIMPULAN}

Berdasarkan pembahasan yang telah dipaparkan, analisis data pemeringkatan webometrics sangat diperlukan bagi sebuah institusi untuk mengukur kekakayaan intelektual yang dimiliki sebuah institusi Perguruan Tinggi Keagamaan Negeri Islam. Adapun indikator dalam pengukuran webometrics antara lain; indikator (S) yaitu banyaknya halaman yang dimiliki sebuah repositori institusi, indikator visibility (v) indikator ini mengukur banyaknya backlink yang dimiliki repositori institusi, indikator Rich File (R) indikator ini mengukur banyaknya file dokumen dalam 
sebuah repositori institusi diantaranya format portable document format (PDF), document (doc), power point (ppt). Indikator Scholar, indikator ini mengukur banyaknya halaman yang ditemuakan dalam google scholar. Hasil analisis webometrics dari 5 repository institusi didapatkan UIN Syarif Hidayatullah menempati peringkat pertama dengan nilai 0,9932, kemudian peringkat kedua adalah UIN Sunan Kalijaga Yogyakarta dengan nilai 0,5486, kemudian peringkat ketiga adalah UIN Sultan Syarif Kasim Riau dengan nilai 0.3916, peringkat keempat adalah UIN Walisongo Semarang dengan nilai 0.2978 kemudian peringkat terakhir adalah UIN Raden Fatah Palembang dengan nilai 0,2171 .

Supaya peringkat webometrik institusi meningkat diperlukan upaya yaitu; Perlunya dibuat sebuah tim teknologi informasi di perpustakaan yang mengkaji tentang search engine optimizer (SEO), perlunya komitment dari semua pihak sivitas akademika dalam mendukung repositori institusi untuk dapat berkembang dan perlunya upaya pelestarian karya akademis yang ada di institusi dengan mengunggah semua konten lokal ke repositori institusi seperti format dokumen pdf, word dan ppt.

\section{DAFTAR PUSTAKA}

Aguillo, I. F. (2009). "Cybermetric Indicators: A Methodological Approach,” 2nd International Workshop on University Web Rangkings. Madrid.

Aguillo, I. F., Ortega, J. L., Fernández, M., \& Utrilla, A. M. (2010). Indicators for a webometric ranking of open access repositories. Scientometrics, 82(3), 477-486. https://doi.org/10.1007/s11192-010-0183-y

Andike, F., \& Dewi, A. O. P. (2017). Evaluasi Kualitas Website Institutional Repository Universitas Gajah Mada Berdasarkan Indikator Webometrics. Jurnal Ilmu Perpustakaan, $6(1)$.

Bachtiar, A. C. (2107). Analisis Webometrics Terhadap Website Repositori Institusi Perguruan Tinggi Indonesia. UIN Sunan Kalijaga Yogyakarta. Retrieved from http://digilib.uinsuka.ac.id/27530/

Coar. (2017). Behaviours and Technical Recommendations of the COAR Next Generation Repositories Working Group. https://doi.org/10.18352/lq.10170/

Helen. (2019). What is Ahrefs.com?| Help Center - Ahrefs. Retrieved November 5, 2019, from https://help.ahrefs.com/en/articles/78203-what-is-ahrefs-com

Lukman, H., D. S., Al-Hakim, S., \& Nadhiroh, I. M. (2019). Pengukuran Kinerja Riset: Teori dan Implementasi. LIPI Press (Vol. 66). Jakarta.

Muntashir. (2011). Analisis webometrics pada perpustakaan perguruan tinggi negeri di Indonesia. Fakultas Ilmu Pengetahuan Budaya Universitas Indonesia. Retrieved from http://lib.ui.ac.id/detail?id=20271517\&lokasi=lokal

Prasetyawan, Y. Y. (2017). Repositori Institusi Universitas Diponegoro: Sebuah Analisis Webometrics. Anuva: Jurnal Kajian Budaya, Perpustakaan, Dan Informasi, 1(1), 41-48. Retrieved from https://ejournal2.undip.ac.id/index.php/anuva/article/view/1903/1245

Sugiyono. (2013). Metode Penelitian Pendidikan Pendekatan Kualitatif, Kuantitatif, dan R\&D. Jakarta: Alfabeta. 
Thelwall, M. (2009). Introduction to Webometrics: Quantitative Web Research for the Social Sciences. Synthesis Lectures on Information Concepts, Retrieval, and Services (Vol. 1). https://doi.org/10.2200/s00176ed1v01y200903icr004

Tiara, K., Rahardja, U., \& Rosalinda, I. A. (2016). Pemanfaatan Google Scholar Dan Citation Dalam Memenuhi Kebutuhan Pembuatan Skripsi Mahasiswa Pada Perguruan Tinggi. Technomedia Journal (TMJ), 1(1).

Westell, M. (2006). Institutional repositories: Proposed indicators of success. Library Hi Tech, 24(2), 211-226. https://doi.org/10.1108/07378830610669583

Yusuf, M. (2017). Metode Penelitian: Kuantitatif, Kualitatif dan Penelitian Gabungan. Jakarta: Kencana.

Zulaikha, S. R., Sholihin, A., Marwiyah, \& Labibah. (2017). Implementasi pengelolaan repositori institusi digital pada perpustakaan PTKIN dan tingkat atas terhadap pemeringkatan di webometrics. Al-Maktabah, 16(1), 1-11. Retrieved from http://journal.uinjkt.ac.id/index.php/al-maktabah/article/view/8082 